\title{
Gender Difference in Teachers' Perception of School Climate and Their Job Performance in Secondary Schools
}

\author{
Ndidiamaka J. Okeke-James, ${ }^{1}$ Adeline N. Anyawu, Phd, ${ }^{2}$ Innocent C. Igbokwe, Phd, ${ }^{3 *}$ and Boniface Emengini ${ }^{4}$ \\ $1,2,3 \& 4$ Nnamdi Azikiwe University, Anambra State, Awka, Nigeria
}

\begin{abstract}
The study investigated gender difference in teachers 'perception of school climate and their job performance in secondary schools in Anambra State, Nigeria. Four research questions and four null hypotheses were used to guide the study. The sample size of 550 teachers representing $10 \%$ of the population and proportionate stratified sampling method was used to identify the sample size. The face validity was established and the reliability was determined through Crobach Alpha for Organizational Climate Index (OCI) and Teachers' Job Performance Questionnaire" (TJPQ) was 0.81 and 0.66 respectively. Pearson Product Moment was used to analyze the research questions and hypotheses. The findings revealed that the relationship between female teachers'perception of open and closed school climate with their job performance was not significant. Based on the findings, the researchers recommended that principals should encourage teachers to devotedly discharge their job performance by maintaining school climate that will enable them discharge their duties with enthusiasm.
\end{abstract}

Keywords: School Climate, Teachers' Perception and Job Performance.

DOI: $10.7176 / \mathrm{JEP} / 11-9-22$

Publication date:March $31^{\text {st }} 2020$

\section{Introduction}

The basic aim and objective of any school organization is to achieve high academic performance and good behaviour of its students. This cannot be attained without good performance of the teachers who are charged to teach and direct the students. Since teachers serve as academic mentor and behaviour modifiers of the students, students' performance and general school success depends on the teachers' job performance. Teachers' job performance is measurable actions, behaviours and outcome that teachers engage in that contribute to the achievement of the school goal (Emengini, 2017). Teachers' job performance involves the activities, duties, behaviours and attitude a teacher is employed to do in the school in order to achieve the educational and school objectives. There are expected teachers' job performances in the school organization. Such job performances among others as identified by in Teachers Service Manual (2015) include;

i. teaching diligently and faithfully the subject assigned to him/her

ii. encouraging the pupils in pursuit of learning;

iii. inculcating by precept and example, the highest regard for morality and other virtues;

iv. being in the classroom or on the school premises, at least 10 minutes, before the time prescribed for the opening of school; and remaining in the school throughout the official hours unless because of illness or other unavoidable cases;

v. being present in the school except for reasons acceptable to the Board or in the case of illness in which his/her absence shall be reported in writing to the principal who shall transmit this to the Board;

Similarly, Adejumobi and Ojikutu (2013) noted that teachers' job performance is measured in terms of teacher's lesson presentation which ranges from introduction of lesson to teachers' mastery of subject, class participation, class control, evaluation and conclusion. From the above, it is clear that teachers' duties are more than just teaching in the class. It includes teachers' activities, duties, behaviours and attitude a teacher is employed to do in the school in order to achieve the educational and school objectives.

Despite the importance the role teachers' job performance play in achieving education success, observations of the researchers show that some teachers do create uncommunicative ambience in the classroom where students can freely ask questions, lacked interpersonal relationship where students can freely approach them with their personal or academic challenges.

One factor that seems to relate to teachers' job performance is school climate. According to Igbokwe (2016), school 
climate is the interaction between human and material resources in any learning environment. Nwagwu (2017) defined school climate as status of human relationships within the operational environment of the educational institution. There are six types of school climate; they include: open, autonomous, controlled, familiar, paternal and closed school climate (Igbokwe, 2016, Nwangwu, 2017 \& Peretomode, 2014).

Open climate reflects a climate where the principal, teachers and students are accessible and actively prepared to jointly achieve school objectives. According to Nwangwu (2017) in an open climate the members of the school are creative, innovative and freely interact with one another. Autonomous climate is a climate that gives teachers freedom to operate. Teachers are given liberty to use their initiative and exercise professional competence while carrying out their duties. In controlled Climate the emphasis is mostly on hard work. Principals dominate all school activities, emphasizes more on school objectives with little attention to consideration and satisfaction of individuals' personal and social needs (Olibie, Uzoechina \& Eziuzor, 2015). Familiar climate is characterized by high consideration on need and interests of individuals in the schools with little emphasis in achieving the school objectives. Paternal climate refers to a climate where the principal is very hardworking, but has no effect on the staff. The principal discourages the emergence of leadership acts from the teachers and attempts to solely initiate all leadership himself (Olibie, Uzoechina \& Eziuzor, 2015). Closed climate according to Collard in (Okorji, Igbokwe \& Ezeugbor, 2016) describes a school where the principal is rigid, unsupportive and controlling while the teachers are intolerant, disrespect, divided and inefficient. Among these school climate types, open and closed climate are pointed as the most prominent in schools (Okorji, Igbokwe \& Ezeugbor (2016). Consequently, this study is interested in open and closed climate.

Open climate is healthy whereas closed climate is unhealthy in achieving general school objectives (Okorji, Igbokwe \& Ezeugbor (2016). A healthly climate is characterized by free interaction and relationship among school members, good students' academic achievement and good teachers' job performance, while a closed (unhealthy climate) is a roadblock to free expression, interaction, students' learning and teachers' performance. One factor that seem to moderate the relationship between school climate and teachers' job performance is teachers' gender.

As male and female teachers differ in their patterns of development their perception of the relationship between school climate and job performance may vary. Tran (2015) observed teachers' gender difference on the relationship between school environment factors and their teaching efficacy. On the other hand, Emengini (2017) and Wanakacha, Aloka and Nyaswa (2018) in their independent studies observed that gender differences did not have effect on teachers to perform their core functions . in view of this variations in opinions, one wonders whether teachers gender moderate the relationship between school climate and teachers' job performance. It is on the basis of this that the need for a study on gender difference in teachers' perception of school climate and their job performance is expedient.

The main purpose of the study was to find out the gender difference in teachers' perception of school climate and their job performance in secondary schools in Anambra State. Specifically, the study sought to determine whether:

1. Male teachers' perception of open school climate predict their job performance in secondary schools in Anambra State;

2. Male teachers' perception of closed school climate predict their their job performance in secondary schools in Anambra State;

3. Female teachers' perception of open school climate predict their job performance in secondary schools in Anambra State;

4. Female teachers' perception of closed school climate predict their job performance in secondary schools in Anambra State;

The following research questions guided the study:

1. Do male teachers' perception of open school climate predict their job performance in secondary schools in Anambra State?

2. Do male teachers' perception of closed school climate predict their job performance in secondary schools in Anambra State?

3. Do female teachers' perception of open school climate predict their job performance in secondary schools in Anambra State?

4. Do female teachers' perception of closed school climate predict their job performance in secondary schools in Anambra State?

The under listed hypotheses were tested at 0.05 level of significance. 
1. Male teachers' perception of open school climate will not significantly predict their job performance.

2.Male teachers' perception of closed school climate will not significantly predict their job performance.

3. Female teachers' perception of open school climate will not significantly predict their job performance

4. Female teachers' perception of closed school climate will not significantly predict their job performance

\subsection{Method}

The study utilized correlational survey research design. The study was carried out in Anambra State. A sample of 550 teachers made up of 77 males and 473 females representing $10 \%$ of the population were involved in the study. In composing the sample, the proportionate stratified sampling and simple random sampling technique were adopted. The stratification was based on education zone and gender. Using simple random sampling technique ten percent of male and ten percent of female teachers from each education zone was drawn from the schools sampled. This gave a sample size of 77 males and 473 females.

The researchers adapted two structured questionnaires for data collection namely: Organizational Climate Index (OCI) and Teachers' Job Performance Questionnaire" (TJPQ) . The first questionnaire, the Organizational Climate Index (OCI) was developed by Hoy, Smith and Sweetland (2002). OCI was 20 item questionnaires which was used to measure school climate. Each item consists of description of school climate type in the school. Items 1-10 consists of description open school climate while items 11-20 was on closed school climate. The second instrument was developed by Emengini (2016) Teachers' Job Performance Questionnaire" (TJPQ) was used to collect information on teachers' job performance.

Each of the questionnaire consist of two parts each A and B. Part A contained an item on the gender of the teacher while Part B contained 20 items each structured on five-point scale of VHE-Very High Extent-5 points, HE-High Extent -4 points, ME-Moderate Extent -3 points, LE-Low Extent-2points and VLE-Very Low Extent-1 point

The questionnaires were validated by three experts; two in Educational Management and Policy Department and one in Measurement and Evaluation. All the experts are lecturers in the Faculty of Education, Nnamdi Azikiwe University.

The reliability of the instrument was ascertained using Cronbach Alpha, this yielded indices of for Organizational Climate Index (OCI) and Teachers' Job Performance Questionnaire" (TJPQ) was 0.81 and 0.66 respectively

Data were collected by the researcher with the help of six research assistants who were teachers in the secondary schools in Anambra State. A total of 550 copies of the questionnaires were distributed but only 418 copies representing 76\% were successfully retrieved and these were used for data analysis.

Pearson Product Moment Correlation was used to answer research questions and test hypotheses. Hypotheses were tested at 0.05 level of significance. Accordingly, the calculated probability value $(P)$ was weighted against the stipulated level of significance so that where $P$ value is less than stipulated level of significance $(0.05)$, the null hypothesis was rejected but where the $P$ value is greater than the stipulated level of significance, the null hypothesis was not rejected. In answering the research questions, the following rule suggested by Mukaka (2012) was used for judging correlation in this work:

\begin{tabular}{|l|l|}
\hline Size of Correlation & Interpretation \\
\hline .90 to $1.00(-.90$ to -1.00$)$ & Very high positive (negative) correlation \\
\hline .70 to $.90(-.70$ to -.90$)$ & High positive (negative) correlation \\
\hline .50 to $.70(-.50$ to -.70$)$ & Moderate positive (negative) correlation \\
\hline .30 to $.50(-.30$ to -.50$)$ & Low positive (negative) correlation \\
\hline .00 to $.30(.00$ to -.30$)$ & Negligible correlation \\
\hline
\end{tabular}




\subsubsection{Results}

Table 1: Pearson's Correlation between male teachers' perception of open school climate and their job performance.

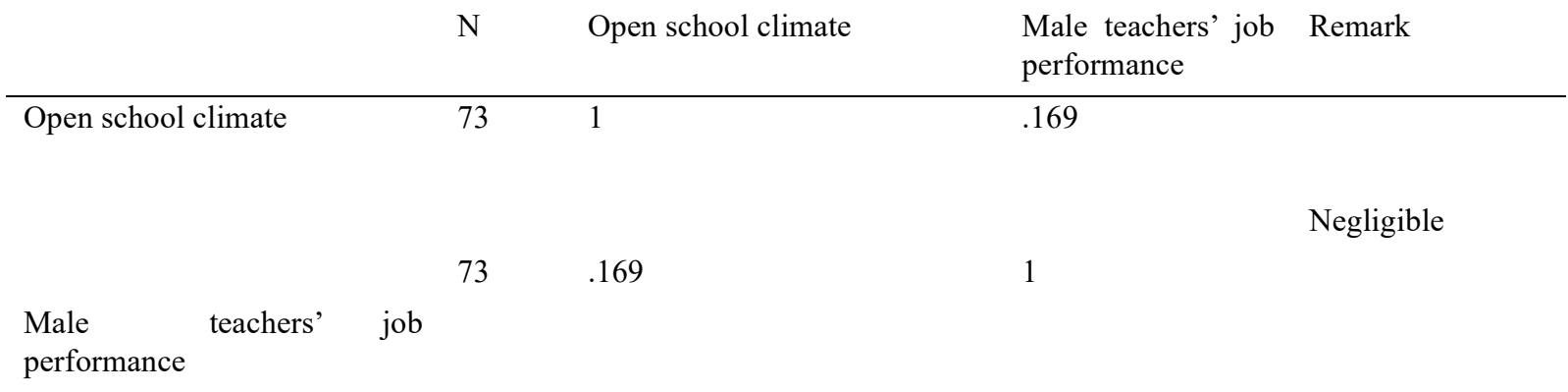

As indicated in Table 1, a negligible positive relationship exists between male teachers' perception of open school climate and their teachers' job performance because the rule of Mukaka (2012) as seen in the method of data analysis, shows that $r(.169)$ is between .00 and .30 . Therefore, the relationship is negligible and positive.

Table 2: Pearson's Correlation between male teachers' perception of closed school climate and their job performance

\begin{tabular}{|c|c|c|c|c|}
\hline & $\mathrm{N}$ & Closed school climate & $\begin{array}{l}\text { Male teachers' job } \\
\text { performance }\end{array}$ & Remark \\
\hline Closed School climate & 73 & 1 & -.487 & \\
\hline & & & & Low \\
\hline $\begin{array}{l}\text { Male teachers' job } \\
\text { Performance }\end{array}$ & 73 & -.487 & 1 & \\
\hline
\end{tabular}

Table 2 revealed that the Pearson's Correlation Coefficient, r. (73) $=-.487$. Going by the rule of Mukaka (2012) as indicated in the method of data analysis, $\mathrm{r}(-.487)$ is between .30 and .50 , therefore, the correlation is low. This is an indication that there is low negative correlation between male teachers' closed school climate and their teachers' job performance in secondary schools in Anambra State.

Table 3. Pearson's Correlation between female teachers' perception of open school climate and their job performance.

\begin{tabular}{llll} 
& $\mathrm{N}$ & Open school climate & $\begin{array}{l}\text { Female teachers' job Remark } \\
\text { performance }\end{array}$ \\
\hline Open school climate & 345 & 1 & -.071
\end{tabular}

Negligible

Female teachers' job $345 \quad-.071$

performance

The results in Table 3 revealed that the Pearson's Correlation Coefficient, r. $(345)=-.071$. Going by the rule of Mukaka (2012) as indicated in the method of data analysis, $r(-.071)$ is between .00 and .30, therefore, the correlation is negligible. This shows that negligible and negative correlations exist between female teachers' perception of open school climate and their job performance in secondary schools in Anambra State. 
Table 4. Pearson's Correlation between female teachers' perception of closed school climate and their job performance.

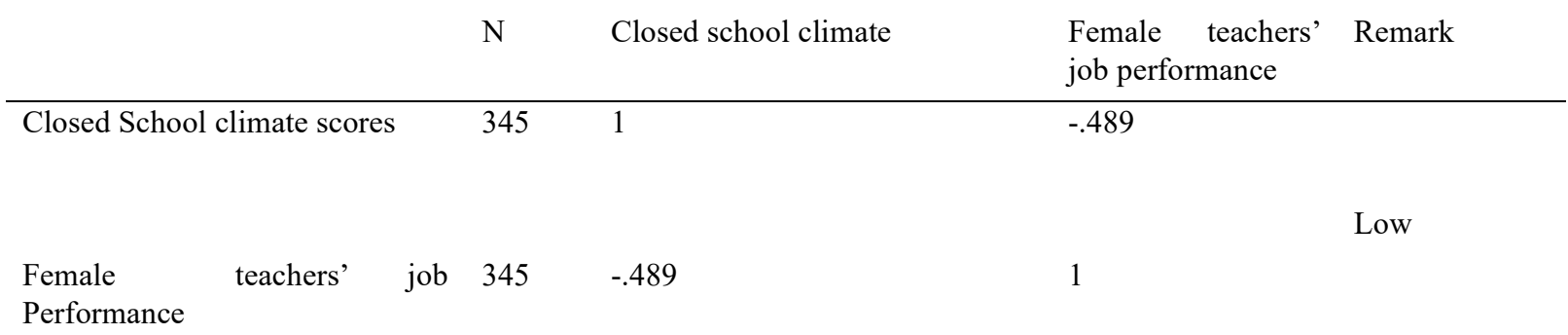

As shown in Table 4, the correlation between female teachers' perception of closed school climate and their teachers' job performance is -.489. This shows that low and negative correlations exist between female teachers' perception of closed school climate and their job performance.

\subsubsection{Discussion}

The findings showed that there is a negligible positive relationship between male teachers' perception of open school climate and their job performance. This agrees with Olibie, Uzoechina and Eziuzorm (2015) who listed genuineness, high spirit of teachers and high thrust as characteristics of open climate. This is in line with opinion of Igbokwe (2016) that open school climate encourages openness and receptive attitude among school members. However, the finding of the null hypothesis indicates that the relationship between the male teachers' open school climate scores and their job performance is not significant.

The finding of this study also shows that there is a low negative relationship exists between the male teachers' perception of closed school climate and their job performance scores. This finding is in tandem with the opinion of Nwangwu (2017). Nwangwu stated that closed climate represents the atmosphere that isolates people, frustrate free association and communication. The finding of the null hypothesis indicates that the relationship between male teachers' closed school climate scores and their job performance scores is not significant. This contradicts the findings Sofoluwe, Akinsolu and Ogbudinkpa (2015) that gender significantly influence job performance

Furthermore, the finding of this study also shows that there is a negligible negative correlation between female teachers' perception of open school climate and their job performance. The relationship shows that there is inverse relationship between female teachers' perception of open school climate relates to a unit increase in and their job performance. The finding of this study disagrees with the opinion of Okorji, Igbokwe and Ezeugbor who asserted that open school climate reflects a school climate where the stakeholders in school- principal and teachers cooperate and support one another. The finding of the null hypothesis indicates that the relationship between female teachers' open school climate scores and their job performance scores is not significant. Put differently, open school climate is a significant factor in predicting female teachers' organizational silence.

Finally, findings of this study that there is a low negative relationship between female teachers' perception of open school climate and their job performance. This means that closed school climate inversely relate to female teachers' job performance. A unit increase in the closed school climate is associated to a unit decrease in level of female teachers' job performance. This finding of the is in line with the opinion of Maniam and Pihie (2017) that closed climate is unhealthy, unfavourable and unfriendly. Closed climate is a learning environment that distort knowledge and information flow. The findings also support Igbokwe (2016) who noted that closed climate is characterized by very high disengagement, high aloofness and low supportiveness among school members. This shows that teachers working under closed climate are less concerned about school objectives, lacked effective interaction, communication and interpersonal relationship.

\section{Conclusion}

The concern of this study was to investigate the relationship between school climate and teachers' job performance. This was in order to examine the gender difference in perception of school climate and teachers job performance. Specifically, this study concludes that there is no significant relationship between open and school climate with male and female job performance. However, as the study shows, a unit increase in the closed school climate level is associated to a unit decrease in level of female teachers' job performance. 


\section{Recommendations}

The following recommendations have been made based on the findings of the study:

1. The principals should be encouraged to embrace leadership style of administration that gives the teachers opportunity to express ideas and critique constructively

2. The principals should integrate teachers in all aspects of decision making that primarily concerns the teachers

3. The principals should create friendly and favourable and working conditions where the teachers relate and share freely

\section{References}

Adejumobi, F., \& Ojikutu, R. (2013). School climate and teacher job performance in Lagos state Nigeria. Discourse Journal of Educational Research. 1(12), .26-36. Retrieved from http://www.resjournals.org/IJER. June, 2013

Emengini, B. (2017). Organizational culture as determinates of teachers'job performance and attitude to work in secondary schools in Anambra state Unpublished Master's degree Thesis. Faculty of Education. Nnamdi Azikiwe University.

Hoy, W. K., Smith, P. A., \&Sweetland, S. R. (2002). The Development of the organizational climate index for high schools: Its measure and relationship to faculty trust. The High School Journal, 86(2), 38-49.

Igbokwe, I. (2016). Relationship between School climate ad teachers'job performance in Secondary Schools in Enugu State. Unpublished Master's degree Thesis. Faculty of Education. Nnamdi Azikiwe University

Maniam, I., \& Pihie, Z. (2017). The mediating effect of school climate on transformational leadership and school effectiveness. International Journal of Humanities Social Sciences and Education, 4(4), 82-87. doi:10.20431/2349-0381.0404009.

Mukaka M.M. (2012). A guide to appropriate use of correlation coefficient in medical research. Malawi Medical Journal, 24(3):69-71

Nwangwu, C. (2017). School climate and educational management. Lagos, Amfitop Books.

Nworgu, B. (2015). Educational research: Basic issues and methodology (2nd ed.). Enugu: University Trust Publishers.

Nwosu, J. (2017) Principals' communication strategies and teachers' job performance in public secondary schools in Ikenne Local Goverment Area of Ogun State. International Journal of Education, Learning and Development 5 (9)1-12

Obikwelu, C., \& Nwasor,V. (2017). Perceived influence of remuneration on teacher motivation in Anambra state secondary schools. Journal of the Nigerian academy of education, 13(1),152-163.

Nigerian Teachers' Service Manual (2015). Lagos: Federal Ministry of Education, Nigeria.

Okorji, P., Igbokwe, I. \& Ezeugbor, C. (2016). Relationship between school climate and principals' job performance in secondary schools. European Scientific Journal, 12, 1857-7881. doi:10.19044/esj.2016

Olibie, E., Uzoechina, G. \& Eziuzorm, G. (2015). Organizational climate types prevailing in public and private secondary schools in Delta North Senatorial Zone of Delta State Nigeria. International Journal of Educational Policy Research and Review, 2, 47-51. doi.org/10.15739/IJEPRR.011

Shamma, F.M. (2018). The influence of gender on teachers' degree of organizational commitment in Arab schools in Isreal. American Journal of Educational Research, 6(4), 349-353.

Sofoluwe, A.O, Akinsolu,A.O \& Ogbundinkpa,1.C.(2015). The relationship between gender, stress and job performance among academic staff in territory in Anambra State, Nigeria. European Science Journal, $11(34) 522-535$

Tran, V. D. (2015). Effects of gender on teachers' perceptions of school environment, teaching efficacy, stress and job satisfaction. International Journal of Higher Education, 4(4). 147-157

Wankacha, C.K. \& Aloka, P.J. (2018). Gender differences in motivation and teacher performance in core functions in Kenyan secondary schools. Academic Journal of Interdisciplinary Studies.7(1),89-95 